\title{
7 止血鑷子の電気メス熱賃防止対策に関する研究
}

\author{
酒井順哉, 吉中平次, 島津久明（鹿児島大病院中央手術部） \\ 住谷健二, 根本 喬（瑞穂医科工業）
}

近年，電気メスには，広範囲な術野の迅速な止血操 作を目的として，スプレー凝固機能を搭載した装置が 市販されるようになったが，その高周波電流のピーク 電圧は, 従来の凝固出力の 2 倍程度に増加している. そのため，ステンレス製止血鎮子や止血鍸子と電気 メスを組み合わせて止血操作を行う際，錋子・銚子を 保持した助手の手に電父入スの高周波電流による電撃 や熱傷が生じることがしばしば発生するようになっ た.

われわれは，この原因として(1)執刀医が，本来切開 モードで使用するべき desiccation（接触凝固）を凝

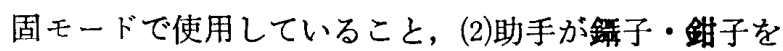
軽く持っているため接触面積が狭くないこと，(3)助手 が鑷子・鈤子を保持していない別の手を術野近くに触 れていること，(4)執刀医が電氛人ス先を銀子・鉬子に 接触させる前に通電することなどであることを明確に
し，第14回日本手術部医学会総会にて報告した.

近年では，絶縁コーティングが施された霹子・鍸子 が市販されているものの, 電気メスの高周波電流を用 いた desiccation 時の熱傷防止には安全性が十分であ ると言えないことが，実験より確かめられた。

今回我々は，ステンレス製鍓子・鎂子に用いる高周 波電流に対する絶縁方法に関して，幾つかの改善方法 を策定し，実験によりその評価を行った．主な，検討 項目は,

（1）絶縁材質の選択について

(2) 絶縁コーティングの厚みについて

（3）鑷子・錸子の耐絶縁構造について

\section{の 3 点である.}

本研究では，その実験結果に基づき臨床使用面でど の程度の安全性が可能になったかについて検討したの でここに報告する.

\section{8 麻酔器ホース連結部におけるフィルタの安全性について}

白井敦史, 小林 䈠, 瓜生伸一（北里大東病院 $\mathrm{ME}$ センタ一部） 北原 啓 (北里大病院 $\mathrm{ME}$ センター部), 渡辺 敏 (北里大東病 院 $\mathrm{ME}$ センター部・病院 $\mathrm{ME}$ センター部・医学部麻酔科)

麻醉器の酸素及び笑気ホース連結 部（本体側）に は，JIS T 7201 (麻醣器) に明記されていないにも かかわらず，フィルタが取り付けられている。これ は，ほこりや鹿などが麻酔器本体へ流入するのを防止 し, 麻醉器の安全性, 信頼性を維持するための手段と 考えられるが，仮にこのフィルタがほこりや塵などに より目詰をりを起こした場合には，流量の低下や供給 压の低下など麻酔器に影響を与える危険性も含んでい る. そのため, 麻醄器本体の点検を行らと同時にフィ ルタ自体の定期的な保守点検を実施することも重要で ある・
現在市販されているほとんどの麻酔器のホース連結 部には，このフィルタが取り付けられているが，保守 点検を行ら際にフィルタを取り外して目視点検する以 外に目詰まりを発見する簡単な点検方法がないことや フィルタを取り外す場合に構造的に複雑になっている 麻酔器が多いことなど保守管理を行う上で問題点も多 W.

今回我々は，このフィルタの目詰まりとそれによる と思われるアラーム作動の事例を経験し, フィルタの 取り外しに苦慮した経験を若干の検討を加え報告す る. 